\title{
HERRSCHERSCHAFT AND HERRSCHERSUFFIX IN CENTRAL-EAST EUROPEAN LANGUAGES
}

The paper resumes a topic the author approached in several instances beginning with 1987: some specific terms referring to the semantic sphere Herrscherschaft. In Romanian, ban, jupîn, stăpîn and probably also cioban reflect the indigenous Thracian substratum; these forms also reflect the archaic Indo-European Herrschersuffix -n-. In Slavic, their equivalent forms ban, župan and stopan reflect either a Late Thracian or (Proto-)Romanian influence. Equally Rom. vătaf reflects the substratum influence, whereas Slavic vatah, vatak, vataš reflects the same borrowing. On the other hand, Slavic gospods belongs to the archaic Proto-Slavic core elements, while cěsaŕb and kъnędzь reflect a Germanic influence. Finally, Rom. boier is an East-Romance innovation derived from bou 'ox' and initially meant 'owner of cattle = rich man', a traditional association between cattle-owners and richness. The word had a large distribution from the early Middle Ages until late in the 20th century.

\section{Introduction}

In a paper written some 15 years ago (Paliga 1987, in Linguistica, Ljubljana) I dared suggest that a series of Romanian and Slavic terms referring to social and political organisation, specifically ban (1) 'master, local leader' and (2) 'coin, money' (2nd sense derived from the 1st one), jupîn (formerly giupîn) 'a master', stăpîn 'a master, a lord', cioban 'a shepherd', rather reflect a compact etymological group of Pre-Romance and Pre-Slavic origin (including cioban, incorrectly considered a Turkish influence, seemingly starting from the erroneous, but largely spread hypothesis that intervocalic $-b$ - in Romanian would rather suggest a newer origin ${ }^{1}$ ). To these, on another occasion, I added the form vătaf, vătah (also with parallels in some Slavic languages, Paliga 1996: 34-36) and on another occasion I analysed the form boier, also spread in many neighbouring languages, which has often been considered either of unknown origin or again of Turkic (not Turkish, i.e. Ottoman) origin (Paliga 1990; see also our main studies gathered together in a single volume, Paliga 1999). The purpose of this paper is:

1. to gather together all the relevant forms in the semantic sphere 'leader, leadership; master, to master, to protect' in Romanian and the neighbouring Slavic languages;

2. to rediscuss them in the light of new data, and - if required - to make the appropriate corrections and additions;

3. to try a plausible reconstruction of those remote times, and of those remote societies in which these forms were in current use as all these terms refer to essential forms of social, economical and political organisation; and some of them are still in current use (e.g. Slovene župan, Romanian ban 'money, coin' and stăpîn 'a master').

4. to suggest further directions of research and discussions.

1 Indeed, intervocalic $-b$ - and $-v$-are lost in Romanian in the words of Latin origin, NEVER in the case of the indigenous Thracian elements as clearly shown by numerous examples, see below further discussions. 


\section{The forms}

\section{Series ban, cioban, jupîn, stăpîn and the archaic Herrshersuffix $-n-$}

I shall only sum up the data presented in my papers mentioned above. The first series is represented by the forms with the basic root *ban-, *pan-, sometimes in compounds (detailed analysis in Paliga 1987):

Ban 'a master', also 'coin, money'. Spread in Romanian, Bulgarian, Serbian-Croatian and Hungarian; in these languages the spelling is ban, bán, and the general meaning is 'local leader'; the sense 'coin' is specific only to Romanian (general, usual sense) and Polish, at dialectal level. The meaning 'coin' is derived from 'master' as Hasdeu brilliantly observed more than a century ago: "The coin (ban) is made under the authority of the local leader (the ban), just as the old English coin sovereign was made under the authority of the sovereign". Similar forms are recorded in: (a) Croatian, Bulgarian ban 'a leader'; (b) Hungarian bán 'a leader at the Hungarian border' (i.e. Croatia); (c) Polish ban 'a coin'. All these forms are not used any more, with the exception of the form ban 'coin' which is the usual modem Romanian form for 'money', and also the subdivision of the national currency leu, lit. 'lion'?

Many analyses have been inclined to generally consider the two meanings as two different forms of different origin, even though the derivation is clear: ban 'coin, money' is the consequence of the first meaning 'master, lord' as already suggested by Hasdeu in the $19^{\text {th }}$ century. What was clear for long is that a similar form is attested in Persian, hence - some assumed - was borrowed by the Turkic groups and then spread all over southeast Europe. This hypothesis puts, first of all, an essential problem: the term ban, just like the others discussed below, are not specific terms to any Turkic language which might be considered as the intermediate idiom between Persian and Central-Southeast Europe. But the situation will become clearer if we refer to the other terms. Such hypotheses rather reflect the once current recourse to Oriental influences, via Turkish or Persian, whenever no other explanation seemed plausible.

Cioban 'shepherd', also 'a recipient, a pot'; meaning 'shepherd' spread over a large area in Southeast and East Europe. Again the two meanings of the same word have been largely analysed separately. To most linguists, they seem to be so remote from each other, that they may be considered as two different words. In fact, both 'shepherd' and 'recipient' reflect an archaic heritage of the same basic meaning: 'to cover, to protect' (1) sheep, and (2) liquids. In addition, the indigenous Thracian origin of cioban was rarely considered starting from the largely spread opinion that intervocalic $-b$ - should have been lost in Romanian words of Thracian origin. This was an automatic hypothesis starting from the erroneous conception that all the Thracian elements of Romanian must follow the rules of pho-

2 Temporarily out of use these years due to inflation, of course! 
netic evolution like the Latin elements; this view was common in the $19^{\text {th }}$ century and, to a large extent, it is still common among many linguists, despite the obvious reality that, in the indigenous elements of Romanian, intervocalic $b$ and $v$ NEVER disappear, and intervocalic $l$ NEVER turns to $r$. About this see below.

Therefore, if cioban is to be rejected its indigenous origin, then other arguments must be looked for. Perhaps decisive in this sense is a still largely spread view that Thracian and Proto- and Early Romanian could not influence the neighbouring languages to such a great extent. Fortunately, in the wake of the remarkable contribution of the Bulgarian school of Thracian studies, we now know that Thracian was still a spoken language when the first Slavic groups passed the Danube at the beginning of the $6^{\text {th }}$ century A.D., and therefore re-analysing now these (and other) terms does not look so absurd as it seemed some years ago. Many false theories have been built up starting from such erroneous principles, and I feel it is high time to correct them or, at least, to draw attention to their being re-analysed.

Briefly, I only note that cioban is a compound: cio-ban (pronounced čo-ban), the second part of which is ban mentioned above.

In order to have a larger and, hopefully, more convincing view of the topic, let us briefly mention two other forms.

3-4. Jupîn, a lso spelled jupân, formerly ğupîn and stăpîn, also sp elled stăpân. Obviously both are again compound forms of the same type like cioban: ğu-pin > jupin, stă-pinn. The only difference is that the second part of the compound witnesses the voiceless parallel $p$ to the voiced $b$, whereas ğu- in ğu-pin is the voiced parallel to the voiceless $\check{c} o$-, $\breve{c u}$ - in cioban, ciuban.

The semantic sphere is also 'a (local) leader, a master'. The term is specific to Romanian (now obsolete, but preserved in the compound a stăpini 'to master, to be master of'), and to some neighbouring languages. The form župan is still preserved in Slovene with the meaning 'mayor', and clearly reflects the archaic, basic meaning: 'a local leader, a master'. Old Slavonic županı and stopan be remembered that stăpîn was correctly noted as a probable Thracian element in Romanian and the neighbouring languages, and this view has been adopted by more and more linguists (this hypothesis was initially sustained by Al. Philippide, who approached the form to German Stab and Sanskrit sthapáyami; this hypothesis was later adopted by Pârvulescu and Gh. Ivănescu).

In an attempt to overview the problem connected to the four forms (ban, cioban, jupin and stăpîn), I suggest the following reference points:

(a) All these forms reflect IE *pā- 'to protect, to feed' and/or *pōi- 'to protect the cattle, to graze'. The two roots are separately recorded in Pokorny and AHD, in the latter case mentioning their probable relationship in Proto-Indo-European (hereafter PIE). 
(b) The semantic sphere is 'to protect (cattle and/or people), to be a master of (cattle, people)', in one case only preerving an archaic parallel 'to protect' - 'recipient' (in Romanian only, and only at dialectal level, in Transylvania).

(c) Seemingly there was an early specialisation of the forms: ban and cioban (čo-ban), therefore with voiced explosive, refer to 'PROTECTING LIVING BEINGS' (cattle and/or people), whereas the forms with unvoiced explosive (stăpîn and jupinn) refer to 'PROTECTING A TERRITORY', therefore got an early administrative and political meaning. The opposition voiced-unvoiced ( $b$ v. $p$ ) was seemingly due to a laryngeal (see below our brief hypothesis about the Thracian laryngeal) or due to a phonetic sequence $\check{c}-b$ as opposed to $\breve{g}-p$ in Thracian.

(d) All these forms preserve the specific Indo-European Herrschersuffix $-n-$.

(e) All these forms must have the same origin as they refer to a specific semantic sphere, have a quite clear IE etymon, have the same development: the Herrschersuffix $-n$-, and are spread specifically in those southeast European languages which reportedly have a Thracian and/or Illyrian influence; some forms are also attested in Persian.

(f) All these forms represent an etymologically compact group; but cioban should probably deserve a more detailed discussion. Anyway, they should not be discussed and analysed separately, or to assume that only some of them may be of indigenous Thracian origin whereas others might be of Turkic (Pre-Ottoman Turkish, as they are attested many centuries before the arrival of the Turks in Europe). A disparate analysis cannot note the common origin and meaning of these forms.

I assume the form cioban is essential to understanding the evolution and distribution of these forms. Practically the indigenous (Thracian or Dako-Mysian) origin of this form in Romanian was rejected on the erroneous ground that intervocalic $b / v$ in Thracian elements must have disappeared in Romanian as it happened in the Latin elements. This is a topic I have repeatedly approached in some of my papers, and am forced to approach it again. It should be remembered that intervocalic $b / v$ is exceptionally preserved in Latin elements too, as in a avea 'to have', avem, aveți 'we have, you have') or turns to $\breve{g}$ as in $u b e r>$ uger 'udder'. This reflects the special situation of $b / v$ in Late Latin, not in Late Thracian. IN ALL THE EXAMPLES I KNOW, THRACIAN INTERVOCALIC $b / v$ IS REGULARLY PRESERVED IN ROMANIAN, as in abur 'vapours' (= Albanian avull, meanwhile accepted as one of the obvious Thracian elements in Romanian, and with obvious intervocalic $b$ ); equally the remarkable parallel of river-names: Rom. Ibru, Bulg. Ibăr, Serbian Ibar (in the sequence - $b r-, b$ would also have disappeared in a word of Latin origin); place-name Deva - Bulg. Plovdiv (Thr. dava, deva 'a fortress'), and many other examples prove the same: intervocalic $b / v$ is always preserved in the indigenous Thracian (Dako-Mysian) elements.

Another argument invoked for the non-indigenous Thracian origin of cioban is the ending - an, which, also according to the Latin heritage of Romanian, would have closed to -în. Again the reference is not complete, as there are indeed obvious indige- 
nous forms which preserve this ending (formerly it must have been a suffix), e:g. suffix -man in place-names like Caraiman, Căliman (with South Slavic parallels also of Thracian and/or Illyrian origin, see extensively our paper for the $8^{\text {th }}$ Thracian Conference in Sofia-Jambol, September 2000, in print, when this paper is being prepared), ortoman (obsolete, rare) 'rich' (obscure origin, most probably indigenous Thracian) etc. Briefly, the existence of forms with final -an, -in, -un (instead of the expected closed vowel $+n$ ) is not an argument against the archaic, indigenous character of these forms as some words of unknown, possibly or probably of Thracian origin, clearly show.

So if Rom. cioban is to be really considered a Turkish (or generally Turkic) influence, other arguments should be invoked. The current hypothesis I know is that indeed cioban ultimately is of IE origin, but via Turkish where it was borrowed from Persian. This is indeed tortuous, and also unsustainable at a forensic analysis. The word is rare in Aromanian (Macedo-Romanian), but - if of Turkish origin - we would expect it to be the current term there; in fact, the current term for 'shepherd' in Aromanian is picurar = Daco-Romanian păcurar < Latin pecurarius - pecus, pecoris. Besides, Romanian has many other terms for the same semantic sphere (the richest in the area): oier < oaie (Latin ovis), păstor < pastor, baci (archaic indigenous term, probaby of Pre-IndoEuropean origin), mocan, also of unknown origin, perhaps of Pre-Indo-European origin as well. In these circumstances, it would be difficult indeed to accept that cioban is a late borrowing from Turkish where, in its turn, was borrowed from Persian.

We must admit that the etymology of cioban is a key point in further investigations; and the same should be said about duşman 'an enemy', an old IE term, but also considered of Turkish origin in Romanian. The arguments are again feeble, and based on the same erroneous assumption that the phonetic evolution in the case of indigenous Thracian words must follow exactly the phonetic evolution from Latin to Romanian. This is valid indeed when the sounds (phonemes) involved were identical, which is not always the case.

\section{Vătaf and a brief survey of the Thracian laryngeal}

I also discussed this form connected to related forms in Romanian dialects (vătav, vătaş, vătaj, vătah) and the neighbouring languages: Ukr. vataha, Pol. wataha, Bulg. $v a t a h$, and Serbian-Croatian vatak. In the Slavic languages, the sense, according to the available dictionaries, is always 'a leader, a master' (therefore similar to the ban-series analysed above). In Romanian, the basic sense is the same, with some peculiarities: (1) a leader of the servants in a boyar's court and/or in a monastery; (2) leader of a hospodar's group; (3) an essential character of the indigenous magic dance of Călus. ${ }^{3}$

The word must ultimately be of indigenous Thracian-Illyrian origin, and some

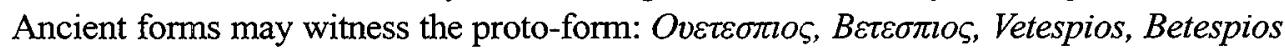
'an epithet for Heros'. In the series of the etymological explanations of Kretschmer,

3 The Călus is one of the main attractions for the foreign tourists in Romania. The complexity of this dance cannot be discussed here 
Barić, Dečev, i.e. the possible relation may be with Alb. vetë 'self, a person'. I also agree that it must be of archaic origin, and also consider that other related Thracian forms may

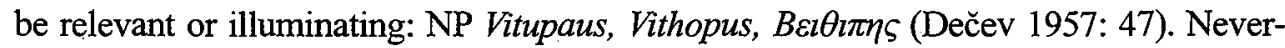
theless the etymon cannot be followed as related to Albanian vetë, but as derived from the IE r oot *wat-, *wet- 'to inspire, to e levate spiritually', hence a lso Lat. vates, - is 'a wit, a prophet', Old Irish faith 'a visionary, a prophet', Germanic god-name Woden, hence Eng. Wednesday, and Norse Odhinn (sometimes identified with Woden).

This ultimate origin is, in my view, the only possibility to explain ALL these forms, both formally and semantically. The spread of these forms all over Central-East Europe cannot be a mere hazard, but the common Thracian or Thraco-Illyrian heritage, even though Romanian must be the intermediary for Ukrainian and Polish forms. The family represented by Rom. vătaf also puts a particularly interesting problem of phonetic evolution: the relations and correspondences between $f, h, s / j, \breve{s}$ and $k$ as witnessed in the languages mentioned, including the Thracian forms attested in the Antiquity. The task is not easy, but we may surmise that the proto-forms had a sound impossible to spell in Greek and Latin. It must have been of laryngeal type, later lost in Romanian, Albanian and also in the Slavic languages which borrowed the term. My view may be better understood if comparing the following examples:

\section{Romanian}

(1) fărîmă 'a small piece'

(2) ceafä '(neck) nape'

(3) căciulă 'a cap'

(4) fluture, a flutura 'a butterfly; to flutter'

(5) hali, hămesit 'to eat; hungry'

(6) abur 'vapours'

(7) barză, pl. berze 'stork'

(8) dîrdîi 'to shiver'

(9) zer, zară 'whey'

(10) zer, zară

(II) zimt 'a dent; a tooth'

(12) laţe '(long) hair'

(13) mal 'river-side'

(14) nană, nene 'older person'

(15) vatră 'a hearth'

\begin{tabular}{|c|c|}
\hline Albanian & $\begin{array}{l}\text { Rom./Alb. } \\
\text { f/th }\left(<^{*} H\right) ; \tilde{a} / \ddot{e} ; r / r r \cdot m / n\end{array}$ \\
\hline thërrimë & $f / t h\left({ }^{*} H\right) ; \tilde{a} / \ddot{e} ; r / r r ; m / n$ \\
\hline qafè & $c i(\breve{c}) / q ; f / f$ \\
\hline kësulë & $c / k ; c i(\check{c}) / s ; l / l ; \breve{a} / \ddot{e}$ \\
\hline fluturonj & $f / f(f l / f l) ; t / t ; u / u$ \\
\hline ha, hamës & $h / h\left(<{ }^{*} H\right) ; m / m$ \\
\hline avull & $a / a ; b / v ; r / l l$ \\
\hline bardhë 'white' & $b / b ; r / r ; z / d h$ \\
\hline dergjem 'I'm ill, sick' & $d / d ;$ erfir \\
\hline dhallë 'buttermilk' & $z / d h ; r / l l$, but also: \\
\hline hirrë 'whey' & $z / h\left(<{ }^{*} H\right) ; r / l l$ \\
\hline dhëmb 'a tooth' & $z / d h ; i m / e ̈ m ; t ̦ / b^{4}$ \\
\hline lesh 'hair; wool' & $l / l ; t / s h$ \\
\hline mal 'a hill' & $m / m ; a / a ; l / l$ \\
\hline nënë 'mother' & $n / n ;$ andën; ă/ë \\
\hline vatër, vatra 'fire' & $v / v ; t r / t r$ \\
\hline
\end{tabular}

The examples may continue, but it is clear, I hope, that (1) Rom. $h$ and $f$, on the one hand, v. Alb. $h, f$ and $t h$ reflect, in some instances, AN OLDER SOUND, convention-

4 In fact, the sequence -imt/-ëmb should be analysed as a group; cf. the relations between the archaic placenames Vințu, Vința (Romania) - Vinča (Serbia) - Văča (Bulgaria), ultimately of Pre-Indo-European origin via Thracian. The Pre-IE root $* W-N$ - has clear correspondences in southeast Europe and even farther West, in Iberia and southern France. 
ally labelled here as laryngeal $* H$; (2) In the indigenous Thracian elements, Alb. $l l$ is newer than Rom. $r$; specifically the evolution, in Albanian, was $r>R$ (as in modern English) $>l l$, as obvious in Rom. abur v. Alb. avull. And, as stated above, indigenous (Thracian) $b / v$ is regularly preserved in these forms.

My reconstruction of the protoform for vătaf/vătah/vătaş/vătaj and its Slavic paralles is ${ }^{*} v \partial t a H$, where the laryngeal ${ }^{*} H$ was later turned into either $f / h / s$ in Romanian and $f / h$ - th $(\theta) / d h(\delta)$ in Albanian. The existence of this laryngeal was brilliantly observed by Hamp in 1973 and rediscussed in Brâncuş 1995, a good hypothesis, sustained and sustainable by other examples, unfortunatelly ignored by many linguists. For sure, it will be rediscussed in the coming years, and will illuminate many obscure points of the phonetic evolution from Thracian (and Illyrian) to modern languages.

The complex correspondences between Romanian and Albanian cannot be discussed here. They just reflect, as stated in some of my previous papers, the complex, multistratified origin of Albanian: Romanised Illyrian (very few reliable examples), ProtoDalmatian, Proto-Romanian and Late-Thracian origins. Albanian, in agreement with most linguists now, must be a Neo-Thracian, not Neo-lllyrian, language with an important Romance heritage, in its turn via at least three routes: Romanised Illyrian, ProtoDalmatian and Proto-Romanian.

\section{An East-Romance innovation: boier}

In Paliga 1990 I made an extensive analysis of Rom. boier in relation with its obviously related forms spread over a large area in Central-East Europe: S.-Cr. bòljarin, pl. boljári; Alb. bujar; Russ. bujarin; Lith. bajoras. These forms refer to a specific social and economic function in the Middle Ages in the areas where these languages were and are spoken. Other forms, like Hung. bo(j)er, Turk. boyar, Pol. bojar refer to such an organisation in the neighbouring areas. Also Med. Lat. boiarones and the institution of bo(i)eronatus reflect a reality specific mainly to Central and Southeast Europe, and also to R ussia (see a nalyses in Arion 1940; Filitti 1925; Filitti 1935; Nistor 1944; Novaković 1913; Stoicescu 1970).

The term is first mentioned by Constantine Porphirogenetos in De ceremoniis aulae byzantinae at the beginning of the $10^{\text {th }}$ century A.D. (905-909). There he mentiones

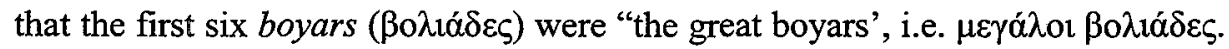

There is an impressive literature referring to the boyars (for which see Paliga 1990). I shall resume here only the main ideas and references. Thus, summing up the historical realities offered by Romanian, Serbian-Croatian and Russian, where the term refers to specifically local realities, and as a step towards explaining the origin of the term, we may assert that:

- The boyars were ALWAYS land-owners; and they were ALWAYS cattle-owners.

- In the course of time, they also acquired certain political, economic and military functions, for the simple reason that they had the financial means to protect not only their properties, but also their country as a whole. 
Generally many linguists were tempted to consider boyar a term of Turkic origin as initially suggested by Miklosich in 1886: 17, root $b a j-$, boj- 'great; high'. There are several variants of this basic theory, all suggesting that the term had been spread a long time before the extension of the Ottoman Empire, so the origin might be Petcheneg or Cuman. There is a major and essential impediment of this old theory: this term is not at all specific to the Turkic area; in Turkish, boyar refer to the Romanian boyars, and there is no argument supporting the idea that this term would have ever been specific in the social and economic organisation of the Turkic groups.

The term must be, as I suggested many years ago, of East-Romance origin, in other words it must be a Proto-Romanian innovation: it is simply derived from bou, pl. boi 'ox, oxen' (< Lat. bos, bovis, Acc. bovem) just like oier 'shepherd' < oaie, pl. oi < Lat. ovis, Acc. ovem. Therefore, the Romanian boier initially meant 'owner of cattle', and this is in full agreement with the traditional, archaic view that 'owner of cattle' or 'owner of sheep' was similar to richness. This obvious association has been preserved over millenia by the association pecus - pecunia 'group of sheep' - 'money'.

This East-Romance term spread to the neighbouring areas, just like kbmotra < Rom. cumătră < Post-Classical Latin *comatra, *cumatra, Classical commater (see other examples in Paliga 1996: Romance and Pre-Romance Influences in South Slavic). There is no other reasonable explanation regarding the origin of this term, and therefore any other hypothesis should be abandoned.

\section{Other Terms}

1. gospods 'a master, lord', especially 'Lord = God'. Reflects the archaic compound *ghostis-potis, and the archaic meaning must have been 'lord of the house'. This seems to be the oldest Slavic term referring to the sphere 'master, lord'. In modern Slavic languages, the meaning is generally 'sir, Mr.' also 'God'. This form was not borrowed in Romanian, where the usual term is domn 'a master, Mr.', also 'God'; the feminine is doamnă; both reflect Lat. dominus, domina. Yet gospodar adj. 'diligent' is a Romanian semantic innovation starting from the Slavic word.

2. cěsaŕrb 'emperor'. Borrowed from either Gothic kaisar in its turn from Latin Caesar or directly from a Late Latin form caesarius (as Skok believes). The term must have been borrowed quite early, before the second palatisation. The term later spread, via documents, as referring to the Bulgarian and Russian emperors. Romanian did not borrow this form; the usual term is împărat $<$ Lat. imperator. A more d etailed discussion r efers to Alb. $m$ bret 'emperor' which reflects a ProtoRomanian borrowing rather than the direct preservation of Lat. imperator (the expected form would be ${ }^{*}$ mbrëtuër, as Landi 1986 argues). Romanian also preserves rege < Lat. rex, regis, Acc. regem.

3. krnędzb 'a princeps'. Borrowed from AHD kuning (cf. Germ. König, Eng. king). This term was also borrowed in Romanian (cneaz), but now it is out of use. 


\section{Stratification of terms}

The forms briefly analysed above allow us to reconstruct their stratification and also to postulate a certain chronology.

In Slavic, gospodb seems to be the oldest form, belonging to the basic Proto-Slavic vocabulary. All the other forms are borrowed from either North Thracian/ ProtoRomanian (ban, jupinn, stăpîn, also cioban, the latter with a restricted circulation, vatah/vataš) or Germanic (cěsaŕb and kъnędzb). Rom. boier is, we may now assume, an East Romance innovation: bou, pl. boi 'ox, oxen' > boier 'owner of cattle $=$ rich man'. This reflects the various influences upon Proto-Slavic and Post-Expansion Slavic ( $4^{\text {th }}$ to $8^{\text {th }}$ centuries A.D.) until it got the form we know from oldest documents.

In Romanian, the series ban, jupîn, stăpîn, also cioban, and vătaf, vătah, vătaş must reflect the indigenous Pre-Romance (Thracian) substratum; impărat and rege reflect the Latin influence; and cneaz the Mediaeval Slavic influence.

This rather simplified scheme roughly reflects the various linguistic evolutions and interferences in this part of Europe. They also partially reflect the archaic Herrscherschaft suffix $-n$ - (ban, jupin, stăpîn, cioban) and, all, the various conceptions about Herrscherschaft across centuries: the master of the house, the master of the land, and the master of the universe = God. And they also fully support the archaeological and historical data referring to Central-, Central-East and S outheast Europe: an a rchaic world striving to adapt to the realities of the $21^{\text {st }}$ millenium.

\section{A final note}

The introduction of our paper for the 8th Congress of Thracology has been published meanwhile in Proceedings of the $8^{\text {th }}$ International Congress of Thracology, ed. Al. Fol, Sofia 2002. The main part (lexicons A, B and C) will be published in ORPHEUS 11.

\section{References}

Arion, Dinu C. 1940. Vlahii, clasă socială în voevodatele româneşti. București.

Bonfante, Giuliano 1966. Influences du protoroumain sur le protoslave? Acta Philologica 5: 53-69.

Brâncuş, Grigore 1983. Vocabularul autohton al limbii române. Bucureşti: Editura Ştiințifică şi Enciclopedică Brâncuş, Gr. 1991. Istoria cuvintelor. Bucureşti: Coresi.

Dečev (Detschew), Dimităr 1952. Charakteristik der thrakischen Sprache. Sofia.

Deð̌ev, D. 1957. Die thrakischen Sprachreste. Wien: R.M. Rohrer.

Duridanov, Iv. 1989. Nochmals zum namen PLЪPDIVЪ, PLOVDIV. Linguistique Balkanique 32, 1: 19-22.

Duridanov, Iv. 1991. Die ältesten slawishen Entlehnungen im Rumänischen. Linguistique Balkanique 34, 1-2: 3-19.

Filitti, I.C. 1925. Clasele sociale în trecutul românesc. București.

Filitti, I.C. 1935. Proprietatea solului în Principatele Române pînă la 1864. Bucureşti.

Ivănescu, Gheorghe 1980. Istoria limbii române. Iaşi: Junimea.

Ivănescu, Gh. 1983. Lingvistică generală şi românească. Timişoara: Facla.

Landi, Addolorata 1986. Considerazioni sulla nota di Al. Rosetti. Studia Albanica 23, 2: 139-144.

Mihăescu, Haralambie 1978. La langue latine dans le sud-est de l'Europe. București-Paris: Editura AcademieiLes Belles Lettres. 
Mihăilă, Gheorghe 1971. Criteriile determinării împrumuturilor slave în limba română. Studii şi cercetări lingvistice 22, 4: 351-366.

Mihăilă, G. 1973. Studii de lexicologie şi istorie a lingvisticii româneşti. București: Editura Didactică şi Pedagogică.

Mihăilă, G. 1974. Dicționar al limbii române vechi (sfirşitul sec. X-inceputul sec. XVI). București: Editura Enciclopedică Română.

Miklosich, Franz 1884. Die türkischen Elemente in den südost- und osteuropäischen Sprachen, I-II. Wien.

Miklosich, F. 1886. Etymologisches Wörterbuch der slavischen Sprachen. Wien: Wilhelm Braumüller.

Nistor, Ion I. 1944. Clasele boiereşti din Moldova şi privilegiile lor. Analele Academiei Române, Memoriile Secțiunii Istorice, seria III, tom XXVI, mem. 17, Bucureşti.

Novaković, Stojan 1913. Baština i boljar u jugoslovenskoj terminologiji srednjega veka. Glas kraljevske Akademije, Beograd, 92: 210-255.

Paliga, Sorin 1987. The social structure of the southeast European societies in the Middle Ages. A linguistic view. Linguistica 27: 111-126.

Paliga, S. 1990. Este boieria o instituție împrumutată? Revista Arhivelor 67, vol. 52, 3: 250-260.

Paliga, S. 1996. Influențe romane și preromane în limbile slave de sud. București: Lucretius.

Paliga, S. 1999. Thracian and Pre-Thracian Studies. București: Lucretius Publishers.

Philippide, Alexandru 1923-1928. Originea românilor, I-II. Iaşi.

Skok, Petar. Južni Sloveni i turski narodi. Jugoslovenski istoriski časopis 2.

Spinei, Victor 1982. Terminologia politiç̆ a spațiului est-carpatic în perioada constituirii statului feudal de sine stătător. Stat, societate, națiune ed. by N. Edroiu, A. Răduțiu and P. Teodor, Cluj 1982: 66-79.

Stoicescu, Nicolae 1970. Sur l'origine des grandes dignités en Valachie et Moldavie. Revue roumaine d'histoire $9,2$.

Stoicescu, N. 1971. Dicționar al marilor dregători din țara Românească şi Moldova, secolele XIV-XVII. Bucureşti: Editura Enciclopedică.

Tăpkova-Zaimova, V. 1962. Sur les rapports entre la population indigène des régions balkaniques et les "barbares" du VIe-VIIe siècle. Byzantinobulgarica 1: 67-78.

Tăpkova-Zaimova, V. 1972. La compétence des sources byzantines sur la survivance de l'ethnie thrace. Thracia I: $223-230$.

Toderaşcu, Ion 1988. Unitatea românească medievală. Bucureşti: Editura Ştiințifică şi Enciclopedică.

Vámbéry, Armin (Hermann) 1878. Etymologisches Wörterbuch der turkotatarischen Sprachen. Leipzig.

Vătăşescu, Cătălina 1997. Vocabularul de origine latină din limba albaneză în comparație cu româna. Bucureşti: Institutul Român de Tracologie, Bibliotheca Thracologica XIX.

\section{Povzetek}

\section{IZRAZI ZA GOSPODSTVO IN PRIPONE ZANJE V SREDNJEVZHODNIH EVROPSKIH JEZIKIH}

Članek prikazuje možnosti glede izvora besed s pomenom "gospod, gospodar" $v$ jezikih jugovzhodnega Balkanskega polotoka. Avtor domneva, da romun. besede ban "gospodar", jupîn, stăpîn "lokalni mogotec, gospodar" in morda tudi cioban "pastir" izvirajo iz traškega substrata in da vsebujejo ide. pripono $-n$ - za tvorbo samostalnikov s pomenom "gospodar". Substratni element je tudi romun. vătaf "vodja, gospodar, glavni služabnik". Slovanske ustreznice ban, župan, stopan, čoban in vatah/vatak so izposojene ali iz pozne traščine ali pa že iz praromunščine.

Za romun. boier se domneva izpeljavo iz bou "govedo" in prvotni pomen "gospodar črede", tj. "bogataš". Beseda se je iz praromunščine razširila v srbščino, bolgarščino in ruščino verjetno $v$ istem času kot cslov. kbmotra iz predhodnika romun. cumătră "botra".

Pri razlagah avtor diskutira o fonetičnih problemih in $v$ nekaj segmentih odgovarja na vprašanje, ali veljajo pri razvoju iz traščine prevzetih romun. besed iste zakonitosti kot pri razvoju avtohtonih romanskih.

Opisane razlage soglašajo $z$ arheološkimi in zgodovinskimi spoznanji, na osnovi katerih se pradomovina Slovanov postavlja severno od romaniziranega dela jugovzhodne Evrope in domneva širitev Slovanov od tod proti zahodu in jugu. 